\title{
Stachybotrydial Selectively Enhances Fibrin Binding and Activation of Glu-plasminogen
}

\author{
Masaaki Sasaoka, Yasuko Wada, Keiji Hasumi
}

Received: July 23, 2007 / Accepted: October 9, 2007

(C) Japan Antibiotics Research Association

\begin{abstract}
Stachybotrydial, a triprenyl phenol metabolite from a fungus, has a plasminogen modulator activity selective to Glu-plasminogen. Stachybotrydial enhanced fibrin binding and activation of Glu-plasminogen (2to 4 -fold enhancement at $60 \sim 120 \mu \mathrm{M}$ ) but not of Lys-plasminogen. Approximately $1.2 \sim 1.6$ moles of $\left[{ }^{3} \mathrm{H}\right]$ stachybotrydial bound to Glu-plasminogen to exert such effects. The selective modulation of the Gluplasminogen function by stachybotrydial may be related to alteration of its conformational status.
\end{abstract}

Keywords nonlysine-analog plasminogen modulator, plasminogen activation, conformation, fibrinolysis, stachybotrydial

\section{Introduction}

The plasminogen/plasmin system is involved not only in fibrinolysis but also in many other physiological and pathological processes requiring localized proteolysis, including inflammation, tissue remodeling, ovulation, tumor metastasis and tissue invasion of pathogens [1 5]. In this system, the zymogen plasminogen is proteolytically activated into plasmin by urokinase-type plasminogen activator (uPA) or tissue-type plasminogen activator (tPA). Circulating plasminogen with an $N$-terminal Glu (Gluplasminogen) is a single-chain glycoprotein with multiple functional domains, which consist of an $N$-terminal peptide, five homologous kringle domains and a trypsin-

K. Hasumi (Corresponding author), M. Sasaoka, Y. Wada: Department of Applied Biological Science, Tokyo Noko University, 3-5-8 Saiwaicho, Fuchu-shi, Tokyo 183-8509, Japan, E-mail: hasumi@cc.tuat.ac.jp like serine protease domain $[6,7]$. The binding of plasminogen to fibrin and cell surfaces localizes fibrinolytic activity on these surfaces [8]. The plasminogen binding is mediated by lysine binding sites located within the kringle domains $[9,10]$. Glu-plasminogen exhibits a tight, spiral structure [11] due to an intramolecular interaction between a lysine residue(s) $\left(\mathrm{Lys}^{50}\right.$ and/or $\left.\mathrm{Lys}^{62}\right)$ in the $N$-terminal peptide and the lysine-binding site in kringle 5 domain [12 15]. The tight conformation of Glu-plasminogen attenuates both its activation and binding to fibrin and cellular receptors [16 18]. Lysine analogs, such as 6aminohexanoic acid, bind to the lysine binding sites and induces a large-scale conformational change in Gluplasminogen $[13,19,20]$, facilitating its activation to plasmin. Conformational regulation of Glu-plasminogen activation is also revealed by using several monoclonal antibodies that bind to kringle domains [21]. Hydrolysis of Glu-plasminogen by plasmin yields a truncated form of plasminogen called Lys-plasminogen, which predominantly has Lys $^{78}$ as an $N$-terminal residue [22, 23]. Lysplasminogen adopts a relaxed, extended conformation, and such conformation is implicated in an increased susceptibility to activation and a high affinity fibrin binding of Lys-plasminogen [13, 16, 24, 25]. Thus, conformational status of plasminogen is implicated in localized activation of plasminogen.

We recently discovered several nonlysine-analog plasminogen modulators such as staplabin/SMTPs and thioplabins [26 34]. These low molecular mass compounds induce conformational change in plasminogen and enhance both plasminogen binding to fibrin and activation of plasminogen, leading to increased fibrinolysis. With respect to induction of conformational change in plasminogen, nonlysine-analogs are similar to lysine analogs. The striking difference between the two types of plasminogen 
modulators is that nonlysine-analogs enhance plasminogenfibrin binding and fibrinolysis, while lysine analogs inhibit these activities. In this study, we have found that stachybotrydial [35], a triprenyl phenol metabolite from the fungus Stachybotrys sp., has distinct properties as compared with the previously identified nonlysine-analog plasminogen modulators. Stachybotrydial selectively enhances fibrin binding and activation of Glu-plasminogen, without increasing such activities of Lys-plasminogen.

\section{Materials and Methods}

\section{Materials}

Proteins and chemicals were from the following sources: human Glu-plasminogen and Lys-plasminogen from Enzyme Research Laboratories (South Bend, IN, USA); two-chain uPA from JCR Pharmaceuticals (Kobe, Japan); two-chain tPA from American Diagnostica (Greenwich, CT, USA); aprotinin from CosmoBio (Tokyo, Japan); 6aminohexanoic acid, fibrinogen, thrombin, plasmin and S-2251 (H-D-Val-Leu-Lys- $p$-nitroanilide) from Sigma (St. Louis, MO, USA); Flavigen tPA $\left(\mathrm{CH}_{3} \mathrm{SO}_{2}\right.$-D-HHT-GlyArg-p-nitroanilide) from Biopool (Umeå, Sweden); glutaryl-Gly-Arg-7-amino-4-methylcoumarin (Glt-Gly-ArgAMC) from Cambridge Research Biochemicals (Cheshire, UK); $\mathrm{Na}^{125} \mathrm{I}$ from Amersham Biosciences (Piscataway, NJ, USA); sodium $\left[{ }^{3} \mathrm{H}\right]$ acetate (methyl $-{ }^{3} \mathrm{H}$ ) from Moravec Biochemicals (Brea, CA, USA).

Stachybotrydial and its congeners F1839-A, -B, -C, and -E were isolated from cultures of Stachybotrys sp. F1839 as described previously [35]. Radioiodination of Gluplasminogen and Lys-plasminogen was performed using the chloramine-T method [30]. The compositions of buffers were: buffer A, $20 \mathrm{mM}$ sodium phosphate and $150 \mathrm{mM}$ $\mathrm{NaCl}, \mathrm{pH}$ 7.4; buffer B, Hanks' balanced salt solution containing $1 \mathrm{mg} / \mathrm{ml}$ bovine serum albumin and $50 \mathrm{mM}$ Hepes, $\mathrm{pH}$ 7.4; buffer C, $50 \mathrm{mM}$ Tris- $\mathrm{HCl}, 100 \mathrm{mM} \mathrm{NaCl}$ and $0.01 \%(\mathrm{wt} / \mathrm{vol})$ Tween $80, \mathrm{pH} 7.4$; buffer D, bovine serum albumin-free buffer B; buffer E, buffer A containing $2.5 \mathrm{mg} / \mathrm{ml}$ gelatin and $0.01 \%$ Tween 80 .

\section{Production and Isolation of $\left[{ }^{3} \mathrm{H}\right]$ stachybotrydial}

Stachybotrys sp. F1839 [35] was grown aerobically at $28^{\circ} \mathrm{C}$ in $15 \mathrm{ml}$ of medium consisting of $30 \mathrm{mg} / \mathrm{ml}$ glucose, $10 \mathrm{mg} / \mathrm{ml}$ soybean meal, $3 \mathrm{mg} / \mathrm{ml}$ meat extract, $3 \mathrm{mg} / \mathrm{ml}$ peptone, $3 \mathrm{mg} / \mathrm{ml}$ yeast extract, $0.5 \mathrm{mg} / \mathrm{ml} \mathrm{KH}_{2} \mathrm{PO}_{4}$, and $0.5 \mathrm{mg} / \mathrm{ml} \mathrm{MgSO}_{4}$. After 91 hours, sodium $\left[{ }^{3} \mathrm{H}\right]$ acetate $(370 \mathrm{MBq})$ was added to the medium, and the culture was further incubated for 29 hours. The resulting culture was extracted three times with 1 volume of 2-butanone. After concentration, the organic extracts were applied to a silica gel column (Wakogel C-200; $10 \times 150 \mathrm{~mm}$ ). The column was developed successively with $30 \mathrm{ml}$ of $n$-hexane, $60 \mathrm{ml}$ of $n$-hexane - ethyl acetate $(4: 1)$ and $60 \mathrm{ml}$ of $n$-hexaneethyl acetate $(3: 2)$. $\left[{ }^{3} \mathrm{H}\right]$ Stachybotrydial was found in the $3: 2$ fraction, which was concentrated and subjected to HPLC on an Inertsil PREP-Sil column (GL Sciences, Tokyo, Japan; $6 \times 250 \mathrm{~mm}$ ) developed with $n$-hexaneethyl acetate $(7: 3)$, yielding $84 \mu \mathrm{g}$ of purified $\left[{ }^{3} \mathrm{H}\right]$ stachybotrydial. The specific radioactivity of the preparation was $117 \mathrm{~Bq} / \mathrm{nmol}$.

\section{Determination of $\left[{ }^{125} I\right]$ plasminogen Binding to Fibrin}

Human fibrinogen $(0.2 \mathrm{mg} / \mathrm{ml})$ in $100 \mu \mathrm{l}$ buffer A was dried in 96-well tissue culture plates by incubating at $37^{\circ} \mathrm{C}$ for $3 \sim 5$ days. Each well received $75 \mu 1$ of human thrombin (0.68 international unit $/ \mathrm{ml}$ in buffer A) and was incubated at $37^{\circ} \mathrm{C}$ for 3 hours to form fibrin clots. The resulting fibrin clots were washed 3 times with $100 \mu \mathrm{l}$ of buffer $\mathrm{A}$ and incubated at $37^{\circ} \mathrm{C}$ for 60 minutes with $50 \mu$ of buffer B containing $50 \mathrm{nM}\left[{ }^{125} \mathrm{I}\right]$ plasminogen in the presence or absence of $20 \mathrm{mM}$ 6-aminohexanoic acid. After washing with buffer A (twice with $200 \mu \mathrm{l}$ and once with $100 \mu$ l), the bound $\left.{ }^{125} \mathrm{I}\right]$ plasminogen was dissolved in $50 \mu \mathrm{l}$ of $0.2 \mathrm{M}$ $\mathrm{NaOH}$ and $2 \%$ (wt $/ \mathrm{vol}) \mathrm{SDS}$ at $37^{\circ} \mathrm{C}$ for 30 minutes. An aliquot $(40 \mu \mathrm{l})$ of the lysate was counted for radioactivity. The specific binding of $\left[{ }^{125} \mathrm{I}\right]$ plasminogen was calculated by subtracting values obtained in the presence of $20 \mathrm{mM}$ 6-aminohexanoic acid (nonspecific binding) from values obtained in its absence (total binding).

\section{Determination of Plasminogen Activation}

The activation of plasminogen into plasmin was assayed in two ways: measurement of initial velocity for plasmin generation using a chromogenic substrate for plasmin (S-2251) and determination of the conversion of $\left[{ }^{125} \mathrm{I}\right]$ plasminogen to $\left[{ }^{125} \mathrm{I}\right]$ plasmin using SDS-polyacrylamide gel electrophoresis. In the former assay, $0.1 \mu \mathrm{M}$ plasminogen and $0.1 \mathrm{mM} \mathrm{S}-2251$ were incubated in buffer C with tPA (20 units $/ \mathrm{ml})$ at $37^{\circ} \mathrm{C}$ for up to 120 minutes with monitoring the change in absorbance at $405 \mathrm{~nm}$. From the slope of the plots of $\mathrm{A}_{405} \mathrm{~nm}$ versus $\mathrm{t}^{2}$ [36], initial velocity of plasmin generation was calculated. In the latter assay, $0.1 \mu \mathrm{M}\left[{ }^{125} \mathrm{I}\right]$ plasminogen was incubated with tPA (600 units $/ \mathrm{ml})$ and aprotinin (1000 kallikrein inhibitor units $/ \mathrm{ml}$ ) in $15 \mu \mathrm{l}$ of buffer $\mathrm{C}$. After incubation at $37^{\circ} \mathrm{C}$ for 120 minutes, the mixture received $4.5 \mathrm{mg}$ of solid urea and $5 \mu \mathrm{l}$ of $3.6 \%(\mathrm{wt} / \mathrm{vol}) \mathrm{SDS}, 3.6 \%(\mathrm{wt} / \mathrm{vol}) 2$ mercaptoethanol, and $0.08 \%$ (wt/vol) bromophenol blue. After heating at $60^{\circ} \mathrm{C}$ for 30 minutes, $10 \mu \mathrm{l}$ of the mixture was subjected to SDS-polyacrylamide gel electrophoresis 
on a $10 \%$ gel, followed by autoradiography.

\section{Determination of the Activities of Plasmin, tPA and uPA}

The activities of plasmin, tPA and uPA were determined at $37^{\circ} \mathrm{C}$ in $50 \sim 80 \mu \mathrm{l}$ of buffer $\mathrm{C}$ using $100 \mu \mathrm{M}$ of S-2251, Flavigen tPA and Glt-Gly-Arg-AMC, respectively, as chromogenic substrates. The enzyme concentrations were: $20 \mathrm{nM}$ for plasmin; 20 units/ml for tPA; 5 units/ml for uPA. The release of $p$-nitroaniline (for S-2251 and Flavigen tPA) or 7-amino-4-methylcoumarin (for Glt-Gly-Arg-AMC) was measured as a change in absorbance at $405 \mathrm{~nm}$ or fluorescence (excitation at $380 \mathrm{~nm}$ and emission at $480 \mathrm{~nm}$ ), respectively.

\section{Determination of $\left[{ }^{125} \mathrm{I}\right]$ Fibrin Degradation}

$\left[{ }^{125} \mathrm{I}\right]$ Fibrin-coated well $\left(20 \mu \mathrm{g}\right.$ of $\left[{ }^{125} \mathrm{I}\right]$ fibrin; $\left.\sim 4 \times 10^{4} \mathrm{cpm}\right)$ prepared as described previously [37] was incubated at $37^{\circ} \mathrm{C}$ for 60 minutes with $70 \mu \mathrm{l}$ of buffer $\mathrm{E}$ containing $0.1 \sim 1$ international unit/ml uPA and $100 \mathrm{nM}$ plasminogen. After incubation, radioactivity released from the $\left[{ }^{125} \mathrm{I}\right] \mathrm{fibrin}$ clot was determined. Value obtained in the absence of plasminogen was used as a blank.

\section{$\left[{ }^{3} \mathrm{H}\right]$ Stachybotrydial Binding to Plasminogen}

Plasminogen $(3.0 \mu \mathrm{M})$ and $\left[{ }^{3} \mathrm{H}\right]$ stachybotrydial $(120 \mu \mathrm{M})$ were incubated at $37^{\circ} \mathrm{C}$ for varying times in $15 \mu \mathrm{l}$ of buffer C. After incubation, the mixture received $450 \mu$ l of acetone and was stored at $-80^{\circ} \mathrm{C}$ for 1 hour. The mixture was centrifuged at $9,000 \times g$ for 5 minutes at $4{ }^{\circ} \mathrm{C}$ to collect plasminogen as an insoluble pellet, which was further washed twice with acetone $(450 \mu \mathrm{l})$. The resulting pellet was dissolved in $50 \mu \mathrm{l}$ of $0.2 \mathrm{M} \mathrm{NaOH}$ and an aliquot (40 $\mu 1)$ was counted for radioactivity. With this acetone wash procedure, plasminogen protein was recovered quantitatively, and $>99.95 \%$ of unbound $\left[{ }^{3} \mathrm{H}\right]$ stachybotrydial was removed.

\section{Results}

Stachybotrydial enhanced the binding of $\left[{ }^{125} \mathrm{I}\right] \mathrm{Glu}-$ plasminogen to fibrin by 1.6- to 2.7-fold at concentrations of $50 \sim 200 \mu \mathrm{M}$ (Fig. 1A). On the other hand, fibrin binding of $\left[{ }^{125} \mathrm{I}\right]$ Lys-plasminogen, a conformationally relaxed plasminogen species, was not elevated by stachybotrydial (Fig. 1B). Four stachybotrydial analogs (F1839A, B, C and E) were inactive at $200 \sim 400 \mu \mathrm{M}$ in enhancing Gluplasminogen binding (Fig. 1A). The structural difference between stachybotrydial and the analogs is that the analogs have a lactam moiety instead of an aromatic dialdehyde structure.
To explore the mechanism of the stachybotrydial effect, we first treated $\left[{ }^{125} \mathrm{I}\right] \mathrm{Glu}$-plasminogen with $120 \mu \mathrm{M}$ stachybotrydial and then assayed for fibrin binding after dilution to reduce stachybotrydial concentration. The binding of the stachybotrydial-pretreated $\left[{ }^{125} \mathrm{I}\right] \mathrm{Glu}$ plasminogen increased depending on the time of pretreatment (Fig. 2A). The stachybotrydial pretreatment at concentrations of $60 \sim 200 \mu \mathrm{M}$ caused a dose-dependent increase in $\left[{ }^{125} \mathrm{I}\right] \mathrm{Glu}$-plasminogen binding (Fig. 2B). These results suggested that an interaction between stachybotrydial and Glu-plasminogen caused increases in fibrin binding. On the other hand, the fibrin binding of stachybotrydial-treated $\left[{ }^{125} \mathrm{I}\right]$ Lys-plasminogen was not increased prominently (Fig. 2B).

The previously isolated plasminogen modulators (such as staplabin/SMTPs and thioplabins) enhance both fibrin binding and activation of plasminogen [27 29, 32]. Similarly, stachybotrydial elevated tPA-catalyzed activation of plasminogen. The stachybotrydial treatment resulted in time- and dose-dependent increases in the activation of Glu-plasminogen (Fig. 3A and B), whereas the activation of Lys-plasminogen was inhibited (Fig. 3B). Similar results were obtained when uPA was used as a plasminogen activator (data not shown). The enhancement of the activation of Glu-plasminogen accompanied an increase in the conversion of Glu-plasminogen to plasmin as shown in Fig. 3C [plasmin consists of two polypeptide chains (A- and B-chains) that are held together by disulfide bonds, and the intensity of the two chains was increased by stachybotrydial]. Stachybotrydial did not enhance the activity of plasmin, tPA and uPA when assayed using synthetic chromogenic substrates (Fig. 3D). Thus, the stachybotrydial effect did not involve direct activation of these enzymes, and it seemed likely that the effect was mediated by the interaction with Glu-plasminogen.

Stachybotrydial enhanced the degradation of fibrin clots. When $\left[{ }^{125} \mathrm{I}\right]$ fibrin was incubated with stachybotrydialtreated Glu-plasminogen and uPA $(0.1$ to $1 \mathrm{IU} / \mathrm{ml})$ the degradation of $\left[{ }^{125} \mathrm{I}\right]$ fibrin was 1.5 - to 2-fold higher than incubations using nontreated Glu-plasminogen (Fig. 4).

To investigate stachybotrydial-plasminogen interaction, radiolabeled stachybotrydial was produced in a culture of Stachybotrys sp. F1839 supplemented with $\left[{ }^{3} \mathrm{H}\right]$ acetate. The activity of the purified $\left[{ }^{3} \mathrm{H}\right]$ stachybotrydial in enhancing Glu-plasminogen activation was comparable to the activity of unlabeled stachybotrydial. When $\left[{ }^{3} \mathrm{H}\right]$ stachybotrydial $(120 \mu \mathrm{M})$ was incubated with $3.0 \mu \mathrm{M}$ Glu-plasminogen for 20 40 minutes, 1 mole of Glu-plasminogen bound $1.2 \sim 1.6$ moles of $\left[{ }^{3} \mathrm{H}\right]$ stachybotrydial (Fig. 5A). Along with the stachybotrydial binding, the rate of tPA-catalyzed activation of the treated Glu-plasminogen increased in a 


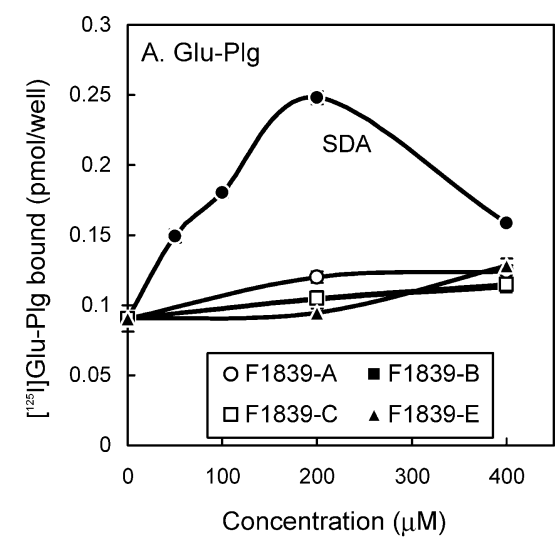

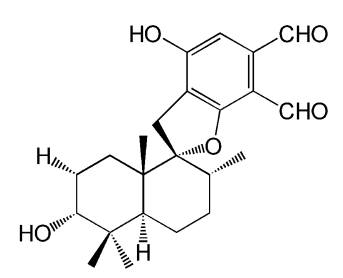

Stachybotrydial (SDA)
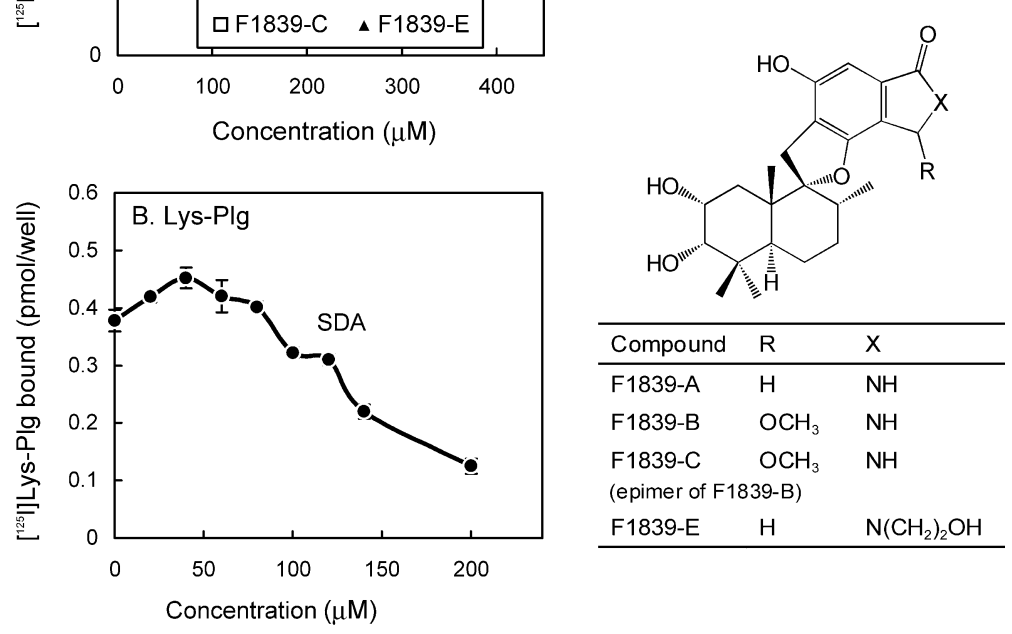

Fig. 1 Effects of stachybotrydial and its analogs on fibrin binding of [ $\left.{ }^{125}\right]$ plasminogen.

The binding of $\left[{ }^{125} \mid\right]$ Glu-plasminogen (Glu-Plg) (A) and [ ${ }^{125}$ I]Lys-plasminogen (Lys-Plg) (B) to fibrin was determined in the presence of the indicated concentrations of the compounds shown in the right. The specific binding values, which was calculated by subtracting values obtained in the presence of $20 \mathrm{mM}$ 6-aminohexanoic acid (nonspecific binding) from values obtained in its absence (total binding), are shown. Each value represents the mean \pm S.D. from triplicate determinations.
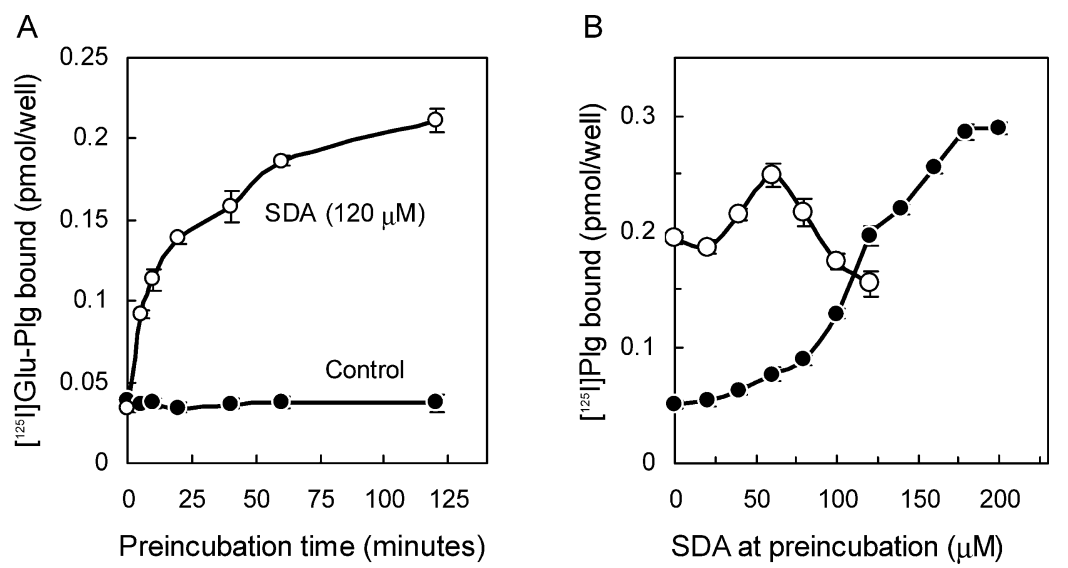

Fig. 2 Effects of stachybotrydial-pretreatment on fibrin binding of [ $\left.{ }^{125}\right]$ plasminogen.

(A) $\left[{ }^{125} \mathrm{l}\right] \mathrm{Glu}$-plasminogen $(3.0 \mu \mathrm{M})$ was preincubated at $37^{\circ} \mathrm{C}$ for the indicated times in the absence $(0)$ and presence $(O)$ of $120 \mu \mathrm{M}$ stachybotrydial (SDA). Subsequently, the mixture was diluted 30 -fold with buffer $D$ and assayed for binding of the pretreated [ $\left.{ }^{125} \mathrm{l}\right] \mathrm{Glu}$ plasminogen to fibrin. (B) [ ${ }^{125}$ I]Glu-plasminogen (-) $(3.0 \mu \mathrm{M})$ or $\left[{ }^{125} \mid\right]$ Lys-plasminogen $(\mathrm{O})(3.0 \mu \mathrm{M})$ was preincubated at $37^{\circ} \mathrm{C}$ for 20 minutes with the indicated concentrations of stachybotrydial, diluted 30-fold with buffer D and assayed for binding of the pretreated [125I]plasminogen to fibrin. The specific binding values are shown. Each value represents the mean \pm S.D. from triplicate determinations 
A

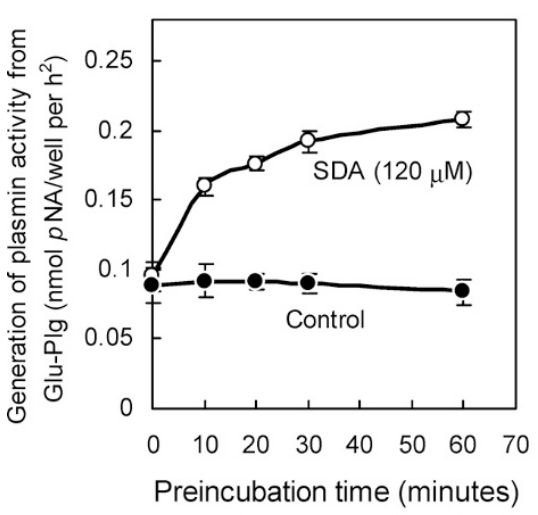

C

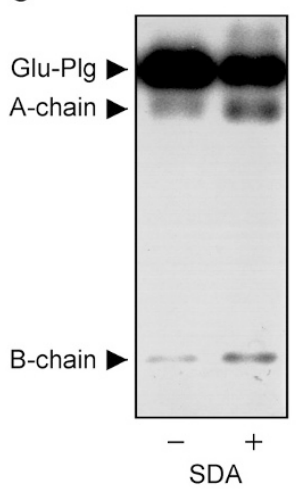

B

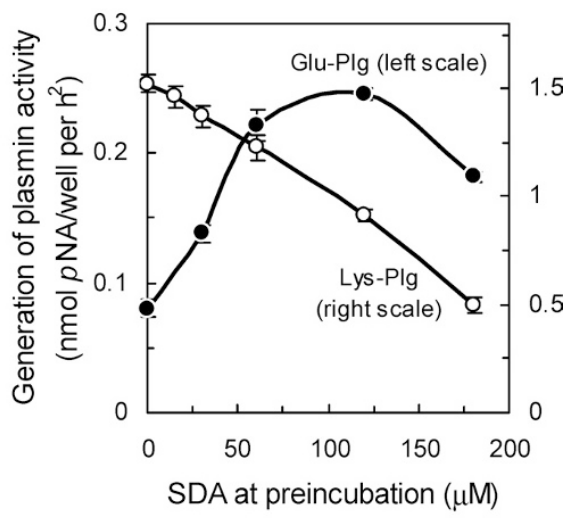

D

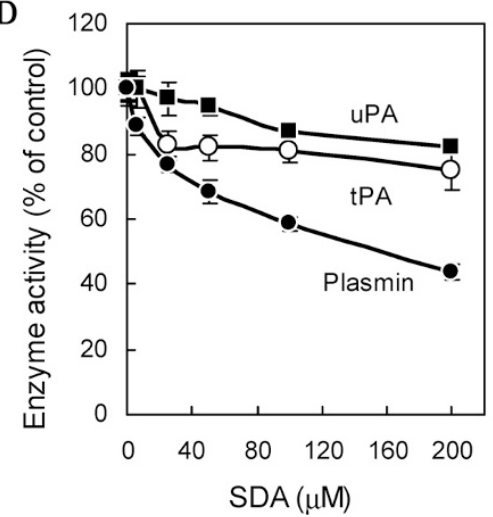

Fig. 3 Effects of stachybotrydial on tPA-catalyzed activation of plasminogen and amidolytic activities of tPA, UPA and plasmin.

(A) Glu-plasminogen $(3.0 \mu \mathrm{M})$ was preincubated at $37^{\circ} \mathrm{C}$ for the indicated times in the absence (-) or presence (O) of $120 \mu \mathrm{M}$ stachybotrydial. Subsequently, the mixture was diluted 30-fold with buffer $\mathrm{C}$ and assayed for plasminogen activation in the presence of tPA. (B) Glu-plasminogen $(3)(3.0 \mu \mathrm{M})$ or Lys-plasminogen $(\mathrm{O})(3.0 \mu \mathrm{M})$ was preincubated at $37^{\circ} \mathrm{C}$ for 20 minutes with the indicated concentrations of stachybotrydial, diluted 30 -fold with buffer $C$ and assayed for plasminogen activation by tPA. Each value represents the mean \pm S.D. from triplicate determinations. (C) $\left[^{125}\right]$ Glu-plasminogen $(3.0 \mu \mathrm{M})$ was preincubated at $37^{\circ} \mathrm{C}$ for 20 minutes in the absence or presence of $120 \mu \mathrm{M}$ stachybotrydial. Subsequently, the mixture was diluted 30-fold and assayed for tPA-catalyzed conversion of [125I]Gluplasminogen to [ ${ }^{125}$ I]plasmin using SDS-gel electrophoresis. Representative autoradiogram is shown. (D) Amidolytic activities of tPA, uPA and plasmin were determined in the presence of the indicated concentrations of stachybotrydial. Each value represents the mean \pm S.D. from triplicate determinations.

similar pattern (Fig. 5A). These results suggested that a stoichiometric binding of stachybotrydial caused Gluplasminogen to be more susceptible to activation. Lysplasminogen also bound $\left[{ }^{3} \mathrm{H}\right]$ stachybotrydial with a level comparable to that of Glu-plasminogen (Fig. 5B), while activation of stachybotrydial-bound Lys-plasminogen was not elevated (see Fig. 3B).

\section{Discussion}

The present results demonstrate that stachybotrydial enhances fibrin binding and activation of Glu-plasminogen.
Four stachybotrydial analogs, which have in common a spiro [4-hydroxy-benzo furan-2(3H), 1' - 6' -hydroxy$2^{\prime}, 5^{\prime}, 5^{\prime}, 8^{\prime}$ a-tetramethyl-decahydronaphthalene] moiety as a core structure, are far less potent than stachybotrydial. The difference between stachybotrydial and the inactive compounds is the presence of an aromatic dialdehyde function in stachybotrydial, and it is likely that this structure is essential to the stachybotrydial action. The stachybotrydial effects may be due to an interaction of the agent with Glu-plasminogen from the following observations: (i) the pretreatment of Glu-plasminogen with stachybotrydial results in increases both in fibrin binding and activation of Glu-plasminogen; (ii) stachybotrydial 
enhances plasmin conversion of Glu-plasminogen without increasing catalytic activity of tPA or uPA; (iii) stachybotrydial can bind to Glu-plasminogen, and the binding at a molar ratio of $1: 1$ is sufficient for exerting the effect. A covalent linkage may be involved in the stachybotrydial-plasminogen binding, because acetone

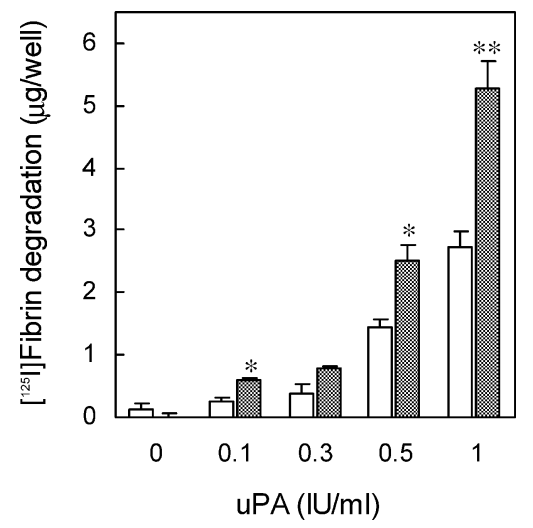

Fig. 4 Fibrinolytic activity of stachybotrydial-treated Gluplasminogen.

Glu-plasminogen $(3.0 \mu \mathrm{M})$ was incubated at $37^{\circ} \mathrm{C}$ for 30 minutes either in the absence (opened bar) or presence (closed bar) of $60 \mu \mathrm{M}$ stachybotrydial. Subsequently, the treated Glu-plasminogen was diluted 30 -fold with buffer $\mathrm{C}$ and incubated with [ $\left.{ }^{125} \mid\right]$ fibrin plate in the presence of the indicated concentrations of UPA to determine fibrin degradation. Each value represents the mean \pm S.D. from triplicate determinations. ${ }^{*}$ and ${ }^{*}, P<0.05$ and $P<0.01$ as compared with control (preincubation in the absence of stachybotrydial) by Student's t-test. washing does not dissociate $\left[{ }^{3} \mathrm{H}\right]$ stachybotrydial from Glu-plasminogen. The aromatic dialdehyde function in the stachybotrydial molecule may play a role in adduct formation with primary amines (e.g., $\varepsilon$-amino group of lysine residue) in plasminogen, while the site of modification remains to be determined.

Stachybotrydial also binds to Lys-plasminogen, but stachybotrydial-binding to Lys-plasminogen does not enhance fibrin binding or activation of Lys-plasminogen. The structural difference between Glu-plasminogen and Lys-plasminogen is that Lys-plasminogen lacks the $N$-terminal peptide. The $N$-terminal peptide of Gluplasminogen interacts with kringle 5 domain in plasminogen and, hence, contributes to maintaining a tight conformation, which is related to a resistance of Glu-plasminogen to activation [14, 15, 38]. Therefore, it seems likely that the stachybotrydial effect is related to a change in the conformational status of Glu-plasminogen. There is a possibility that the binding of stachybotrydial to Gluplasminogen appears to result in it adopting a conformation similar to Lys-plasminogen. If so, the fibrin binding and activation of stachybotrydial-treated Glu-plasminogen should be comparable to those of Lys-plasminogen. The data in Fig. 2B show that the level of fibrin binding of stachybotrydial-treated Glu-plasminogen is comparable to that of Lys-plasminogen. On the other hand, the activation of stachybotrydial-treated Glu-plasminogen is elevated by 3 -fold as compared with nontreated Glu-plasminogen, but the level is $1 / 6$ the level of the activation of Lysplasminogen (Fig. 3B). These results suggest that, although
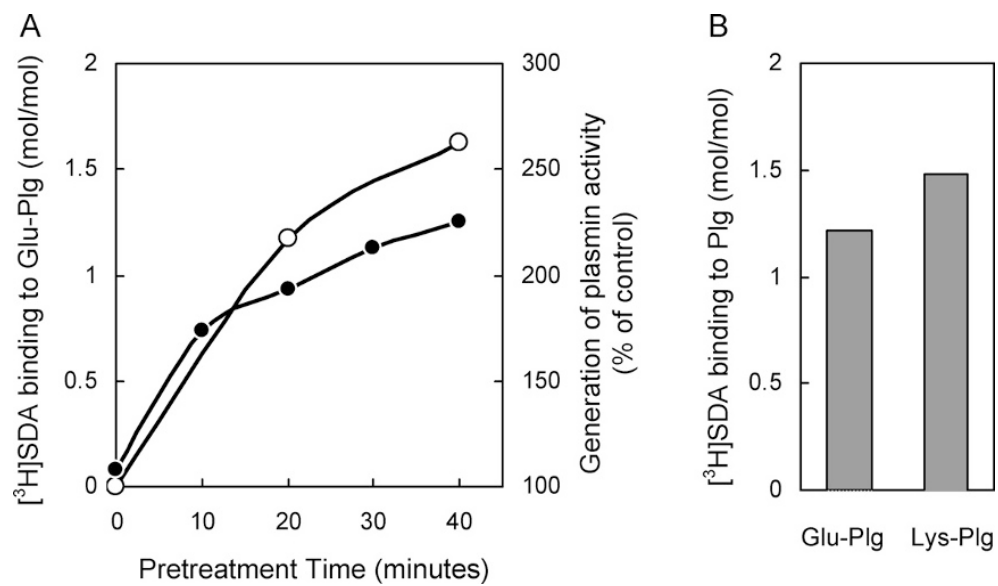

Fig. 5 Binding of $\left[{ }^{3} \mathrm{H}\right]$ stachybotrydial to plasminogen.

(A) Glu-plasminogen $(3.0 \mu \mathrm{M})$ was incubated with either $\left[{ }^{3} \mathrm{H}\right]$ stachybotrydial $(120 \mu \mathrm{M})$ or nonlabeled stachybotrydial $(120 \mu \mathrm{M})$ at $37^{\circ} \mathrm{C}$ for the indicated times. Subsequently, the amount of $\left[{ }^{3} \mathrm{H}\right]$ stachybotrydial bound was determined in duplicate (O). tPA-catalyzed activation of nonlabeled stacybotrydial-treated Glu-plasminogen was determined in triplicate after 30-fold dilution (-). (B) Glu-plasminogen (3.0 $\mu \mathrm{M})$ or Lys-plasminogen $(3.0 \mu \mathrm{M})$ was incubated with $120 \mu \mathrm{M}\left[{ }^{3} \mathrm{H}\right]$ stachybotrydial at $37^{\circ} \mathrm{C}$ for 20 minutes, and $\left[{ }^{3} \mathrm{H}\right]$ stachybotrydial binding was determined in duplicate. 
stachybotrydial modulates the conformation of Gluplasminogen, the resulting conformation is somewhat different from that of Lys-plasminogen.

Lysine analogs, such as 6-aminohexanoic acid, bind to the lysine binding sites in Glu-plasminogen and induces a large-scale conformational change in Glu-plasminogen [13, $19,20]$. This is mainly attributed by the disruption of an intramolecular interaction between a lysine residue(s) in the $\mathrm{N}$-terminal peptide and the lysine-binding site in kringle 5 domain. Although lysine analogs facilitate the activation of Glu-plasminogen through such a mechanism, these are inhibitory to fibrinolysis because lysine analogs inhibit plasminogen-fibrin binding, which is essential for fibrinolysis. With respect to induction of conformational change in Glu-plasminogen, stachybotrydial and other nonlysine-analogs (staplabin/SMTPs and thioplabin) are similar to lysine analogs. In contrast to lysine analogs, stachybotrydial and other nonlysine-analog plasminogen modulators enhance plasminogen-fibrin binding and fibrinolysis. Furthermore, stachybotrydial, which exhibits Glu-plasminogen-specific activity, is distinct from staplabin/SMTPs and thioplabin, which enhance fibrin binding and activation of both Glu-plasminogen and Lysplasminogen [27 29]. Thus, stachybotrydial represent a unique class of nonlysine-analog plasminogen modulator.

Acknowledgments The authors are grateful to Dr. Akira Endo for encouragement. This work was supported in part by a grant from the Japan Society for the Promotion of Science.

\section{References}

1. Ossowski L, Biegel D, Reich E. Mammary plasminogen activator: correlation with involution, hormonal modulation and comparison between normal and neoplastic tissue. Cell 16: 929-940 (1979)

2. Opdenakker G, Van Damme J. Cytokines and proteases in invasive processes: molecular similarities between inflammation and cancer. Cytokine 4: 251-258 (1992)

3. Carmeliet P, Collen D. Gene targeting and gene transfer studies of the plasminogen/plasmin system: implications in thrombosis, hemostasis, neointima formation, and atherosclerosis. FASEB J 9: 934-938 (1995)

4. Tryggvason K, Höyhtyä M, Salo T. Proteolytic degradation of extracellular matrix in tumor invasion. Biochim Biophys Acta 907: 191-217 (1987)

5. Boyle MD, Lottenberg R. Plasminogen activation by invasive human pathogens. Thromb Haemost 77: 1-10 (1997)

6. Sottrup-Jensen L, Claeys H, Zajdel M, Petersen TE, Magnussen S. The primary structure of human plasminogen: isolation of two lysine-binding fragments and one "mini-" plasminogen (MW, 38,000) by elastase-catalyzed-specific limited proteolysis. Prog Chem Fibrinolysis Thrombolysis 3: 191-209 (1987)

7. Forsgren M, Raden B, Israelsson M, Larsson K, Heden LO. Molecular cloning and characterization of a full-length cDNA clone for human plasminogen. FEBS Lett 213: 254-260 (1987)

8. Plow EF, Herren T, Redlitz A, Miles LA, Hoover-Plow JL. The cell biology of the plasminogen system. FASEB J 9: 939-945 (1995)

9. Wu HL, Wu IS, Fang RY, Hau JS, Wu DH, Chang BI, Lin TM, Shi GY. The binding of plasminogen fragments to cultured human umbilical vein endothelial cells. Biochem Biophys Res Commun 188: 703-711 (1992)

10. Miles LA, Dahlberg CM, Plescia J, Felez J, Kato K, Plow EF. Role of cell-surface lysines in plasminogen binding to cells: identification of alpha-enolase as a candidate plasminogen receptor. Biochemistry 30: 1682-1691 (1991)

11. Mangel WF, Lin B, Ramakrishnan V. Characterization of an extremely large, ligand-induced conformational change in plasminogen. Science 248: 69-73 (1990)

12. Christensen U. The AH-site of plasminogen and two $C$ terminal fragments. A weak lysine-binding site preferring ligands not carrying a free carboxylate function. Biochem. J 223: 413-421 (1984)

13. Marshall JM, Brown AJ, Ponting CP. Conformational studies of human plasminogen and plasminogen fragments: evidence for a novel third conformation of plasminogen. Biochemistry 33: 3599-3606 (1994)

14. An SS, C. Carreno C, Marti DN, Schaller J, Albericob F, Llinas M. Lysine-50 is a likely site for anchoring the plasminogen $N$-terminal peptide to lysine-binding kringles. Protein Sci 7: 1960-1969 (1998)

15. Cockell CS, Marshall JM, Dawson KM, CederholmWilliams SA, Ponting CP. Evidence that the conformation of unliganded human plasminogen is maintained via an intramolecular interaction between the lysine-binding site of kringle 5 and the $N$-terminal peptide. Biochem J 333: 99-105 (1998)

16. Lucas MA, Fretto LJ, McKee PA. The binding of human plasminogen to fibrin and fibrinogen. J Biol Chem 258: 4249-4256 (1983)

17. Nesheim ME, Fredenburgh JC, Larsen GR. The dissociation constants and stoichiometries of the interactions of Lysplasminogen and chloromethyl ketone derivatives of tissue plasminogen activator and the variant delta FEIX with intact fibrin. J Biol Chem 265: 21541-21548 (1990)

18. Hajjar KA, Nacman RL. Endothelial cell-mediated conversion of Glu-plasminogen to Lys-plasminogen. Further evidence for assembly of the fibrinolytic system on the endothelial cell surface. J Clin Invest 82: 1769-1778 (1988)

19. Christensen U, Mølgaard L. Positive co-operative binding at two weak lysine-binding sites governs the Glu-plasminogen conformational change. Biochem J 285: 419-425 (1992) 
20. Mølgaard L, Ponting CP, Christensen U. Glycosylation at Asn-289 facilitates the ligand-induced conformational changes of human Glu-plasminogen. FEBS Lett 405: 363-368 (1997)

21. Madoiwa S, Arai K, Ueda Y, Ishizuka M, Mimuro J, Asakura S, Matsuda M, Sakata Y. A battery of monoclonal antibodies that induce unique conformations to evolve cryptic but constitutive functions of plasminogen. J Biochem (Tokyo) 121: 278-287 (1997)

22. Violand BN, Castellino FJ. Mechanism of the urokinasecatalyzed activation of human plasminogen. J Biol Chem 251: 3906-3912 (1976)

23. Fredenburgh JC, Nesheim ME. Lys-plasminogen is a significant intermediate in the activation of Glu-plasminogen during fibrinolysis in vitro. J Biol Chem 267: 26150-26156 (1992)

24. Ramakrishnan V, Patthy L, Mangel WF. Conformation of Lys-plasminogen and the kringle $1 \sim 3$ fragment of plasminogen analyzed by small-angle neutron scattering. Biochemistry 30: 3963-3969 (1991)

25. Peltz SW, Hardt TA, Mangel WF. Positive regulation of activation of plasminogen by urokinase: differences in $\mathrm{Km}$ for (glutamic acid)-plasminogen and lysine-plasminogen and effect of certain alpha, omega-amino acids. Biochemistry 21: 2798-2804 (1982)

26. Shinohara C, Hasumi K, Hatsumi W, Endo A. Staplabin, a novel fungal triprenyl phenol which stimulates the binding of plasminogen to fibrin and U937 cells. J Antibiot 49: 961-966 (1996)

27. Takayasu R, Hasumi K, Shinohara C, Endo A. Enhancement of fibrin binding and activation of plasminogen by staplabin through induction of a conformational change in plasminogen. FEBS Lett 418: 58-62 (1997)

28. Hasumi K, Ohyama S, Kohyama T, Ohsaki Y, Takayasu R, Endo A. Isolation of SMTP-3, -4, -5 and -6, novel analogs of staplabin, and their effects on plasminogen activation and fibrinolysis. J Antibiot 51: 1059-1068 (1998)

29. Ohyama S, Wada Y, Hasumi K. Antibiotic A10255 (thioplabin) enhances fibrin binding and activation of plasminogen. J Antibiot 55: 83-91 (2002)

30. Tachikawa K, Hasumi K, Endo A. Enhancement of plasminogen binding to U937 cells and fibrin by complestatin. Thromb Haemost 77: 137-142 (1997)

31. Kikuchi T, Hasumi K. Enhancement of plasminogen activation by surfactin $\mathrm{C}$ : augmentation of fibrinolysis in vitro and in vivo. Biochim Biophys Acta 1596: 234-245 (2002)

32. $\mathrm{Hu} \mathrm{W}$, Ohyama $\mathrm{S}$, Hasumi K. Activation of fibrinolysis by SMTP-7 and -8, novel staplabin analogs with a pseudosymmetric structure. J Antibiot 53: 241-247 (2000)

33. $\mathrm{Hu} \mathrm{W}$, Kitano $\mathrm{Y}$, Hasumi K. SMTP-4D, -5D, -6D, -7D and $-8 \mathrm{D}$, a new series of the non-lysine-analog plasminogen modulators with a D-amino acid moiety. J Antibiot 56: 832-837 (2003)

34. Ohyama S, Harada T, Chikanishi T, Miura Y, Hasumi K. Nonlysine-analog plasminogen modulators promote autoproteolytic generation of plasmin(ogen) fragments with angiostatin-like activity. Eur J Biochem 271: 809-820 (2004)

35. Sakai K, Watanabe K, Masuda K, Tsuji M, Hasumi K, Endo A. Isolation, characterization and biological activities of novel triprenyl phenols as pancreatic cholesterol esterase inhibitors produced by Stachybotrys sp. F-1839. J Antibiot 48: 447-456 (1995)

36. Verheijen JH, Mullaart E, Chang GTG, Kluft C, Wijngaards G. A simple, sensitive spectrophotometric assay for extrinsic (tissue-type) plasminogen activator applicable to measurements in plasma. Thromb Haemost 48: 266-269 (1982)

37. Inoue T, Hasumi K, Sugimoto M, Endo A. Enhancement of fibrinolysis by plactins: structure-activity relationship and effects in human U937 cells and in mice. Thromb Haemost 79: 591-596 (1998)

38. An SS, Marti DN, Carreno C, Alberico F, Schaller J, Llinas M. Structural/functional properties of the Glu1-HSer57 Nterminal fragment of human plasminogen: conformational characterization and interaction with kringle domains. Protein Sci 7: 1947-1959 (1998) 